\title{
A Prospective Study of Neurologic Disorders in Hospitalized Patients With COVID-19 in New York City
}

Jennifer A. Frontera, MD, Sakinah Sabadia, MD, Rebecca Lalchan, DO, Taolin Fang, MD, Brent Flusty, DO, Patricio Millar-Vernetti, MD, Thomas Snyder, MD, Stephen Berger, MD, Dixon Yang, MD, Andre Granger, MD, Nicole Morgan, MD, Palak Patel, MD, Josef Gutman, MD, Kara Melmed, MD, Shashank Agarwal, MD, Matthew Bokhari, MD, Andres Andino, MD, Eduard Valdes, MD, Mirza Omari, MD, Alexandra Kvernland, MD, Kaitlyn Lillemoe, MD, Sherry H.-Y. Chou, MD, MSc, Molly McNett, RN, PhD, Raimund Helbok, MD, PhD, Shraddha Mainali, MD, Ericka L. Fink, MD, Courtney Robertson, MD, Michelle Schober, MD, Jose I. Suarez, MD, Wendy Ziai, MD, David Menon, MD, PhD, Daniel Friedman, MD, David Friedman, MD, Manisha Holmes, MD, Joshua Huang, MSc, Sujata Thawani, MD, Jonathan Howard, MD, Nada Abou-Fayssal, MD,

Penina Krieger, MPhil, Ariane Lewis, MD, Aaron S. Lord, MD, Ting Zhou, MD, D. Ethan Kahn, DO, Barry M. Czeisler, MD, Jose Torres, MD, Shadi Yaghi, MD, Koto Ishida, MD, Erica Scher, RN, MPH, Adam de Havenon, MD, Dimitris Placantonakis, MD, PhD, Mengling Liu, PhD, Thomas Wisniewski, MD, Andrea B. Troxel, ScD, Laura Balcer, MD, MSCE, and Steven Galetta, MD

Neurology ${ }^{\circledR}$ 2021;96:e575-e586. doi:10.1212/WNL.0000000000010979

\section{Abstract}

\section{Objective}

To determine the prevalence and associated mortality of well-defined neurologic diagnoses among patients with coronavirus disease 2019 (COVID-19), we prospectively followed hospitalized severe acute respiratory syndrome coronavirus 2 (SARS-CoV-2)-positive patients and recorded new neurologic disorders and hospital outcomes.

\section{Methods}

We conducted a prospective, multicenter, observational study of consecutive hospitalized adults in the New York City metropolitan area with laboratory-confirmed SARS-CoV-2 infection. The prevalence of new neurologic disorders (as diagnosed by a neurologist) was recorded and in-hospital mortality and discharge disposition were compared between patients with COVID-19 with and without neurologic disorders.

\section{Results}

Of 4,491 patients with COVID-19 hospitalized during the study timeframe, 606 (13.5\%) developed a new neurologic disorder in a median of 2 days from COVID-19 symptom onset. The most common diagnoses were toxic/metabolic encephalopathy $(6.8 \%)$, seizure (1.6\%), stroke (1.9\%), and hypoxic/ischemic injury (1.4\%). No patient had meningitis/encephalitis or myelopathy/myelitis referable to SARS-CoV-2 infection and 18/18 CSF specimens were reverse transcriptase PCR negative for SARS-CoV-2. Patients with neurologic disorders were more often older, male, white, hypertensive, diabetic, intubated, and had higher sequential organ failure assessment (SOFA) scores (all $p<0.05$ ). After adjusting for age, sex, SOFA scores, intubation, history, medical complications, medications, and comfort care status, patients with COVID-19 with neurologic disorders had increased risk of in-hospital mortality (hazard ratio [HR] 1.38, 95\% confidence interval [CI $1.17-1.62, p<0.001)$ and decreased likelihood of discharge home (HR 0.72, 95\% CI 0.63-0.85, $p<0.001$ ).

\section{Conclusions}

Neurologic disorders were detected in $13.5 \%$ of patients with COVID-19 and were associated with increased risk of in-hospital mortality and decreased likelihood of discharge home. Many observed neurologic disorders may be sequelae of severe systemic illness.

\author{
Correspondence \\ Dr. Frontera \\ jennifer.frontera@ \\ nyulangone.org
}

\section{RELATED ARTICLE}

Patient Page

The Impact of COVID-19 on Developing Neurologic Disorders

Page e647

\section{MORE ONLINE}

\section{ค Podcast}

Dr. Jason Crowell speaks with Dr. Jennifer Frontera about neurology and COVID-19 in New York City. NPub.org/dq64lv

\section{- CME Course}

NPub.org/cmelist

\footnotetext{
From the New York University Grossman School of Medicine (J.A.F., S.S., R.L., T.F., B.F., P.M.-V., T.S., S.B., D.Y., A.G., N.M., P.P., J.G., K.M., S.A., M.B., A.A., E.V., M.O., A.K., K.L., Daniel Friedman, David Friedman, M.H., J.H., S.T., J.H., N.A.-F., P.K., A.L., A.S.L., T.Z., D.E.K., B.M.C., J.T., S.Y., K.I., E.S., D.P., M.L., T.W., A.B.T., L.B., S.G.), New York'University of Pittsburgh School of Medicine (S.H.-Y.C., E.L.F.), PA'The Ohio State University (M.M., S.M.), Columbus'Medical University of Innsbruck (R.H.), Austria'The Johns Hopkins University School of Medicine (C.R., J.I.S., W.Z.), Baltimore, MD'University of Utah School of Medicine (M.S., A.d.H.), Salt Lake City; and University of Cambridge (D.M.), UK.

Go to Neurology.org/N for full disclosures. Funding information and disclosures deemed relevant by the authors, if any, are provided at the end of the article.
} 


\section{Glossary}

aHR = adjusted hazard ratio; CI = confidence interval; COVID-19 = coronavirus disease 2019; EMR = electronic medical record; GCS-NeuroCOVID = Global Consortium Study of Neurologic Dysfunction in COVID-19; ICD-10 = International Classification of Diseases-10; ICH = intracerebral hemorrhage; ICU = intensive care unit; IDSA = Infectious Diseases Society of America; IQR = interquartile range; LOS = length of stay; NYU = New York University; RT-PCR = reverse transcriptase PCR; SAH = subarachnoid hemorrhage; SARS-CoV-2 = severe acute respiratory syndrome coronavirus 2; SOFA = Sequential Organ Failure Assessment.

The prevalence of neurologic findings in patients with severe acute respiratory syndrome coronavirus 2 (SARS-CoV-2) infection ranges from $3.5 \%$ to $84 \%$ across studies. ${ }^{1-5}$ Reported coronavirus disease 2019 (COVID-19)-related neurologic disorders include encephalopathy, anosmia, dysgeusia, headache, stroke, seizure, acute necrotizing encephalopathy, hypoxic ischemic brain injury, encephalitis, and demyelinating polyneuropathy. ${ }^{6}$ However, discrepancies in methodology, neurologic event definitions, cohort size, and ascertainment have contributed to variable reporting. Furthermore, there is a paucity of prospective data evaluating neurologic findings among patients with COVID-19.

In this study, we aimed to prospectively identify the prevalence of specific neurologic diagnoses among patients with laboratory-confirmed SARS-CoV-2 infection and to determine the associated risk of in-hospital death compared to patients with COVID-19 without neurologic disorders. We additionally aimed to compare hospital complications and discharge disposition between these groups. In a secondary analysis, we compared patients with COVID-19 whose neurologic disorders occurred prior to, or at the time of admission, to patients who developed neurologic disorders later during hospitalization.

\section{Methods}

\section{Study Design and Patient Cohort}

A prospective, observational study was conducted including patients hospitalized between March 10, 2020, and May 20, 2020. Inclusion criteria were age $\geq 18$ years, hospital admission, and reverse transcriptase PCR (RT-PCR)-positive SARSCoV-2 infection. Exclusion criteria were SARS-CoV-2 RT-PCR negative test or no test performed, or evaluation in an outpatient or emergency department setting only (without hospital admission). Common data elements, case report forms, and the data repository were developed following the study protocol established by the Global Consortium Study of Neurologic Dysfunction in COVID-19 (GCS-NeuroCOVID), an international study including 189 adult and pediatric sites endorsed by the Neurocritical Care Society. ${ }^{7}$ The first level of screening for inclusion was performed by the emergency department or admitting team, wherein a neurology consult would be triggered according to routine protocol for patients with new or worsened neurologic disorders. All inpatients evaluated by a neurologist across the health system were automatically added to a common list in the electronic medical record (EMR). This list was screened twice daily for study inclusion. Neurologic diagnoses were coded among SARSCoV-2 RT-PCR-positive patients who were evaluated by a neurologist and found to have a new neurologic disorder (as defined below), excluding recrudescence of old neurologic deficits. SARS-CoV-2-infected patients under investigation were kept on the screening list until test results were finalized. Patients with COVID-19 with neurologic diagnoses were compared to SARS-CoV-2 RT-PCR-positive patients (aged $\geq 18$ years) without neurologic diagnoses admitted during the same timeframe. Patients with COVID-19 who were prospectively excluded due to "no new neurologic disorder" after evaluation by a neurologist were included in the control group. Only initial patient admissions were included; readmissions were excluded.

\section{Standard Protocol Approvals, Registrations, and Patient Consents}

This study was approved with a waiver of authorization and informed consent by the New York University (NYU) Grossman School of Medicine Institutional Review Board.

\section{Setting}

We included patients admitted to 4 NYU Langone hospitals (NYU Langone Tisch/Kimmel, Brooklyn, Winthrop, and Orthopedic Hospitals) located in Manhattan, Brooklyn, and Mineola, NY. During the COVID-19 New York City surge encompassing the time frame of this study, bed capacity was expanded and pre-COVID-19 admission and discharge criteria were followed. All transfers during this time period were accepted per protocol. The determination of level of care remained the same as during prepandemic times. All 4 hospitals utilize the same EMR (Epic Systems Corporation, Madison, WI) and information technology center and have integrated clinical protocols for patient management. Inpatient neurology teams covering all 4 sites included the stroke service (staffed by board-certified vascular neurologists), neurocritical care service (staffed by board-certified, neurology trained neurointensivists), acute inpatient neurology service, and neurology consult service. Patients with primary neurologic diagnoses (e.g., stroke, intracranial hemorrhage, encephalitis, seizure, neuromuscular disorders) were admitted to a neurology service (stroke, neurocritical care, general neurology) irrespective of COVID-19 status. Patients with a non-neurologic primary diagnosis and concomitant neurologic disorders (e.g., toxic/metabolic 
encephalopathy) were evaluated by a neurology consult service. Neurointensivists routinely consult on all patients with cardiac arrest per hospital protocol. During the COVID-19 New York City surge, neurologists and neurointensivists routinely cross-covered medicine and intensive care unit (ICU) services that comprised SARS-CoV-2-positive patients with primary medical diagnoses, increasing the probability of case identification in this cohort. ${ }^{8,9}$ All patients identified as having a possible neurologic disorder who were not on a primary neurology service were seen by a neurology consult service to ensure continuity of care and standardized neurologic evaluation.

\section{Neurologic Diagnoses}

Neurologic diagnoses were categorized as toxic/metabolic encephalopathy, stroke (ischemic, intracerebral/intraventricular hemorrhage, spontaneous subarachnoid hemorrhage $[\mathrm{SAH}]$ ), hypoxic/ischemic brain injury, seizure, neuropathy (including Guillain-Barré syndrome), myopathy, movement disorder, encephalitis, meningitis, myelitis, and myelopathy. Diagnostic criteria followed the guidelines established by the GCSNeuroCOVID consortium. ${ }^{7}$ Toxic/metabolic encephalopathy was coded for patients with temporary/reversible changes in mental status in the absence of focal neurologic deficits or primary structural brain disease, excluding patients in whom sedative or other drug effects or hypotension (mean arterial pressure $<60 \mathrm{~mm} \mathrm{Hg}$ ) were judged, on clinical grounds, to explain presentation. This diagnosis category also excluded patients in whom another specific neurologic diagnosis was present that could account for the observed examination findings. Etiologies included electrolyte abnormalities, uremia, liver failure, acid/base disorders, sepsis/active infection, hypertension, hypoxia, or hypercarbia. Ischemic and hemorrhagic strokes were diagnosed according to American Heart Association/American Stroke Association guidelines. ${ }^{10}$ Ischemic strokes and TIAs were diagnosed and adjudicated by a board-certified vascular neurologist and verified by brain imaging. Traumatic intracranial hemorrhages were excluded and ischemic strokes with hemorrhagic conversion were coded as ischemic strokes. Hypoxic/ ischemic brain injury was diagnosed among survivors of cardiac arrest with new CNS dysfunction, and among patients with prolonged or severe hypoxia or hypotension with new neurologic deficits and characteristic radiographic findings on head CT or MRI. Seizures were diagnosed clinically by the treating neurologist or electrographically by an epileptologist. Guillain-Barré syndrome was diagnosed according to international clinical, laboratory, and electrophysiologic criteria. Brighton diagnostic certainty level I and II patients were included. ${ }^{11-13}$ Meningitis, encephalitis, and myelitis were diagnosed according to Infectious Diseases Society of America (IDSA), International Encephalitis Consortium, and American Academy of Neurology guidelines. ${ }^{14-18}$ Initial neurologic diagnoses documented in the medical record were adjudicated by the abstracting physician (neurology attending or resident) following the criteria listed above. Subspecialty adjudication was performed for ischemic and hemorrhagic stroke diagnoses by subspecialist coauthors (K.I., S.Y., J.T., K.M., A.L.). Seizure diagnoses and EEG records were reviewed and adjudicated by epileptologist coauthors (Daniel Friedman, M.H.).

\section{Clinical Management}

A health system-wide inpatient COVID-19 treatment algorithm was developed by the hospital infection control and infectious diseases departments, which broadly followed IDSA guidelines for the treatment and management of COVID-19. ${ }^{19}$ A protocol of early prone positioning was promoted for patients prior to intubation. Therapeutic anticoagulation was continued during hospitalization in patients with an underlying indication. In patients without a prior known indication, serial D-dimer levels were checked every 48 hours and therapeutic anticoagulation (monitoring heparin or enoxaparin specific Xa levels) was recommended in patients with D-dimer levels $>10,000 \mathrm{ng} / \mathrm{mL}$ and suggested in those with D-dimer levels between 2,000 and 10,000 ng/mL. Prophylactic dosing of antithrombotics was recommended for patients with D-dimer levels $<2000 \mathrm{ng} / \mathrm{mL}$. In patients with high suspicion for a venous thromboembolic event, oral anticoagulation could be considered for at least 3 months following discharge. During the timeframe of this study (prior to publication of the RECOVERY trial ${ }^{20}$ ), corticosteroids could be considered in patients with bilateral opacities on chest imaging and $\mathrm{PaO}_{2} / \mathrm{FiO}_{2}<250 \mathrm{~mm} \mathrm{Hg}$, as long as the patient did not have an active bacterial infection and was not immunosuppressed. Corticosteroids could also be used for other indications, such as brain tumor, autoimmune disease, chronic obstructive pulmonary disease exacerbation, refractory septic shock, or suspected adrenal insufficiency.

\section{Data Collection}

We collected common data elements developed by the GCSNeuroCOVID consortium. ${ }^{7}$ Demographics, past neurologic history, admission laboratory values, and in-hospital outcomes (including in-hospital mortality, discharge disposition, ventilator days, and hospital length of stay [LOS]) were recorded. The maximum recorded Sequential Organ Failure Assessment (SOFA) score was used to assess severity of illness; this has been shown to be predictive of organ failure and in-hospital mortality. ${ }^{21-23}$ Patients could be coded for multiple different neurologic diagnoses. Neurologic diagnoses coding was performed by attending neurologists and neurology resident physicians during data abstraction applying the diagnostic criteria listed above. Past neurologic history was assessed via manual chart review and validated by EMR data query based on ICD-10 diagnoses. Data were recorded in a REDCap database.

\section{Study Outcomes}

The coprimary study outcomes were the prevalence of specific new neurologic diagnoses among SARS-CoV-2-positive hospitalized patients and in-hospital mortality rates compared between patients with COVID-19 with and without neurologic disorders. Secondary outcomes included the time from COVID-19 symptom onset to neurologic disorder onset, the time from neurologic disorder onset to admission, common COVID-19 hospital complications (acute respiratory failure 
requiring mechanical ventilation and acute renal failure), discharge disposition, hospital LOS, and ventilator days.

\section{Statistical Analyses}

Demographic variables, past neurologic history, laboratory values, and in-hospital outcomes were compared between patients with COVID-19 with and without a neurologic disorder using the Mann-Whitney $U$ (Wilcoxon rank-sum) for non-normally distributed continuous variables and $\chi^{2}$ test or Fisher exact test for categorical values, as appropriate. A Cox proportional hazards model was fit for the time to in-hospital death using a timedependent neurologic disorder covariate (to account for immortal time bias and the risk of neurologic disorders violating the proportional hazards assumption over the hospitalization period) and adjusting for confounders including age, sex, race, week of admission, hospital location, past medical history (hypertension, diabetes), past neurologic history, maximum SOFA score recorded during hospitalization, hospital complications of acute renal failure or intubation, comfort care only status, and treatment with therapeutic anticoagulation, hydroxychloroquine, corticosteroids, or lopinavir/ritonavir. These confounders were selected based on known predictors of in-hospital death, biological plausibility, and bivariate associations within our own data. To avoid time to event bias among patients who were discharged, a dummy variable of 75 days was used as the event time for right censored patients who were not dead or discharged to hospice. Seventy-five days was selected based on the prolonged LOS observed in this cohort (maximum LOS 71.4 days). All analyses were conducted using IBM SPSS Statistics for Windows version 25 (IBM, Armonk, NY).

\section{Data Availability}

De-identified data will be made available to qualified investigators upon written request to the corresponding author.

\section{Results}

Of 12,990 hospitalized adult patients during the study time frame from March 10 through May 20, 2020, 1,072 (8.2\%) were evaluated by a neurology service. Of these 1,072, 948 ( $88 \%)$ had a new neurologic disorder as diagnosed by a neurologist. We excluded 328/948 (35\%) who had a negative SARS-CoV-2 test and 14/948 (1.5\%) who were not tested (figure). A total of 606/948 (64\%) patients with new neurologic disorders were SARS-CoV-2 RT-PCR positive and included in the analysis. During the same time frame, 3,885/ 12,042 (32\%) SARS-CoV-2-positive patients were hospitalized without a neurologic disorder. The overall prevalence of neurologic disorders among hospitalized patients with COVID-19 was 13.5\% (606/4,491). Among patients with COVID-19 with neurologic disorders, the most common were toxic/metabolic encephalopathy (309/606, 51\%), stroke (84/ $606,14 \%)$, seizure $(74 / 606,12 \%)$, and hypoxic/ischemic brain injury (65/606, 11\%; table 1$)$. No patient had meningitis, encephalitis, myelitis, or myelopathy referable to SARS-CoV-2 infection. Among patients with seizure, 34/74 (46\%) had no prior history of seizure or epilepsy. Of 27 patients with COVID-19 who underwent CSF analyses, 18 had SARS-CoV2 RT-PCR testing and all 18 were negative (table 2 ).

The median time from first COVID-19 symptom (e.g., fever, cough, nausea, vomiting, diarrhea) to neurologic disorder onset was 2 days (interquartile range [IQR] 0-13) and the median time from hospital admission to first neurologic symptom was -0.6 days (IQR -1.8 to 4.1 ), indicating that most patients had neurologic symptoms prior to admission, but after initial COVID-19 symptom onset. Overall, 419/606 (69\%) patients with neurologic disorders developed neurologic symptoms prior to hospital admission. Only 10 (2\%) patients developed neurologic symptoms prior to traditional viral symptoms associated with COVID-19 (cough, shortness of breath, fever, sore throat, gastrointestinal abnormalities), while 263 (43\%) developed neurologic and traditional COVID-19 symptoms at approximately the same time, and 326 (54\%) developed neurologic symptoms after traditional COVID-19 symptoms in a median of 12 days (IQR 5-22). The majority of patients who developed neurologic symptoms prior to or at the same time as traditional COVID-19

Figure Flowchart of Patient Inclusion and Exclusion

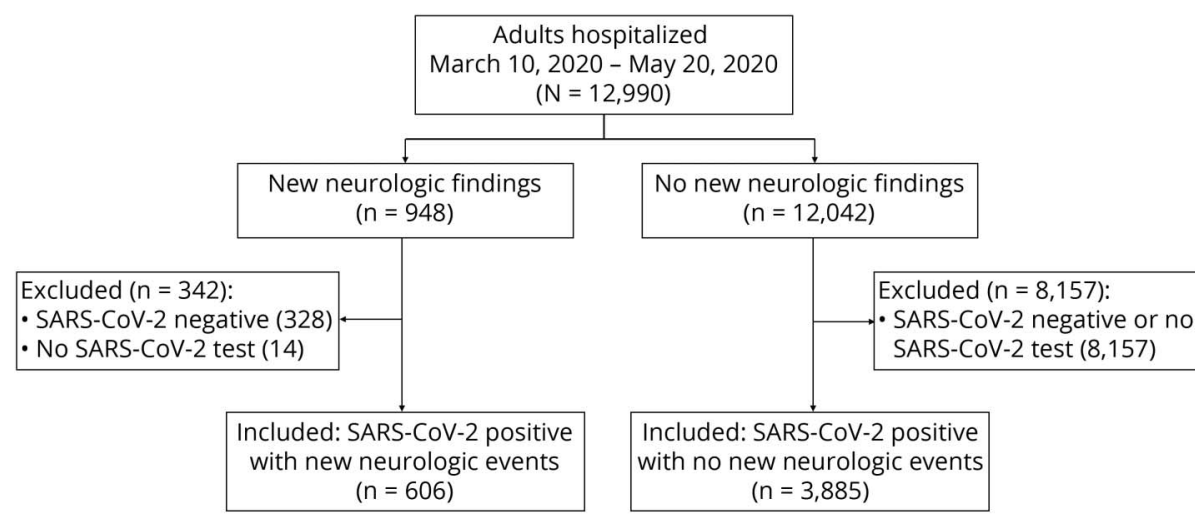

SARS-CoV-2 = severe acute respiratory syndrome coronavirus 2 . 
Table 1 Prevalence of Neurologic Disorders Among Patients Hospitalized With Severe Acute Respiratory Syndrome Coronavirus 2 Infection

\begin{tabular}{|c|c|}
\hline Variable & $\begin{array}{l}\text { Patients }(n=4,491), \\
n(\%)\end{array}$ \\
\hline Any new neurologic disorder & $606(13.5)$ \\
\hline \multicolumn{2}{|l|}{ Neurologic disorders } \\
\hline Toxic/metabolic encephalopathy & $309(6.8)$ \\
\hline Stroke (any type) & $84(1.9)$ \\
\hline Ischemic/TIA & $61(1.4)$ \\
\hline $\begin{array}{l}\text { Intracerebral/intraventricular } \\
\text { hemorrhage }\end{array}$ & $20(0.4)$ \\
\hline Spontaneous subarachnoid hemorrhage & $3(0.1)$ \\
\hline Seizure (clinical or electrographic) & $74(1.6)$ \\
\hline Hypoxic/ischemic brain injury & $65(1.4)$ \\
\hline Movement disorder & $41(0.9)$ \\
\hline Neuropathy & $35(0.8)$ \\
\hline Myopathy & $21(0.5)$ \\
\hline Guillain-Barré syndrome & $3(0.1)$ \\
\hline Encephalitis/meningitis & 0 \\
\hline Myelopathy/myelitis & 0 \\
\hline
\end{tabular}

symptoms had neurologic symptom onset prior to hospitalization (9/10 [90\%] and 256/263 [97\%], respectively). Of the 326 patients who developed neurologic disorders after COVID-19 symptom onset, 172/326 (53\%) had neurologic disorder onset while hospitalized.

Compared to patients who developed neurologic findings prior to or at the time of admission, patients who were diagnosed with neurologic disorders after admission were significantly older, and were more severely ill based on SOFA scores, intubation rates, and acute renal failure rates (table 3 ). Patients who had neurologic disorders postadmission were more often diagnosed with stroke, hypoxic/ischemic brain injury, seizure, neuropathy, and myopathy (all $p<0.05$ ). Patients diagnosed with neurologic disorders after admission were less likely to be discharged home than those with events prior to or at the time of admission.

Compared to the 3,885 patients with COVID-19 hospitalized during the same time frame without neurologic disorders, patients with neurologic disorders were significantly older (median age 71 vs 63 years), male (66\% vs 57\%), and white (63\% vs $45 \%)$. Comorbidities including hypertension, diabetes, atrial fibrillation, venous thromboembolism, and history of neurologic illness were also significantly more common among those with neurologic diagnoses (table 4). Similarly, patients with neurologic disorders were more severely ill with higher SOFA scores (median 4 vs $3, p<$ 0.001 ), higher rates of invasive mechanical ventilation ( $40 \%$ vs $19 \%, p<0.001)$, higher rates of acute renal failure $(28 \%$ vs $12 \%, p<0.001)$, and higher rates of ICU admission ( $40 \%$ vs $19 \%, p<0.001)$. The majority of patients with neurologic events were admitted to a general internal medicine service (425/600 [70\%]), while only 33/600 (6\%) were admitted to a neurology service. Admission inflammatory biomarkers (interleukin-6, D-dimer) were increased in patients with neurologic disorders compared to those without (both $p<$ 0.01 , table 4). Patients with neurologic disorders were more likely to receive corticosteroids and therapeutic anticoagulation (for clinical indications such as atrial fibrillation, mechanical heart valves, or venous thromboembolism and for elevated D-dimer levels) than patients without neurologic disorders (table 4). Anticoagulation use was significantly associated with intracerebral hemorrhage (ICH) $(17 / 20$ [85\%] of patients with $\mathrm{ICH}$ were anticoagulated vs $1,128 / 4,471$ [25\%] of those without ICH, $p<0.001)$ and SAH $(3 / 3$ [100\%] of patients with SAH were anticoagulated vs 1,142 / $4,488(25 \%)$ of those without SAH, $p=0.003){ }^{24,25}$

We observed higher rates of in-hospital mortality and lower rates of discharge home among patients with COVID-19 with neurologic disorders compared to those without (table 4). After adjusting for age, sex, race, date, and location of hospitalization, past history of medical and neurologic diseases, severity of illness (invasive mechanical ventilation and SOFA scores), acute renal failure, comfort care status, and differences in COVID-19-specific medication administration (therapeutic anticoagulation, hydroxychloroquine, corticosteroid, lopinavir/ritonavir use), the occurrence of a neurologic disorder was significantly associated with in-hospital death $(35 \%$ with a neurologic disorder died vs $19 \%$ without, adjusted hazard ratio [aHR] 1.38, 95\% confidence interval [CI] 1.17-1.62, $p<0.001)$. Similarly, after adjusting for the same factors and excluding patients who died or were in comfort care, the occurrence of a neurologic disorder was associated with a significantly reduced likelihood of discharge home (aHR 0.72, 95\% CI 0.63-0.85, $p<0.001$ ). Median hospital LOS (9.8 vs 5.9 days) and ventilator days (11.8 vs 5.0) were longer among those with neurologic disorders compared to those without (both $p<0.001$ ). Corticosteroid use was independently associated with a reduced risk of inhospital mortality (aHR 0.81, 95\% CI 0.69-0.95, $p=0.009$ ).

\section{Discussion}

In this large prospective study of neurologic disorders among hospitalized patients with COVID-19, 13.5\% of patients had a neurologic diagnosis, most commonly toxic/metabolic encephalopathy, stroke, seizure, or hypoxic/ischemic brain injury. The occurrence of a neurologic disorder in the context of SARS-CoV-2 infection was associated with a $38 \%$ increased risk of in-hospital death and a $28 \%$ reduced likelihood of discharge home, after adjusting for other factors. 
In contrast to prior retrospective studies that focused on the conglomerate prevalence of nonspecific neurologic symptoms (agitation, dysexecutive function, myalgia, dizziness, headache ${ }^{1-4}$ ) along with neurologic diagnoses (e.g., stroke, seizures, Guillain-Barré syndrome), we applied rigorous, standardized diagnostic criteria to identify the prevalence of specific neurologic diagnoses in a prospective fashion. All patients with neurologic disorders were evaluated by a neurologist, which strengthens the validity of the diagnoses. Unlike studies that included patients with suspected COVID-19 (without laboratory confirmation) ${ }^{26}$ or categorized neurologic disorders based on clinical suspicion alone (without imaging, laboratory, or pathologic diagnosis verification), ${ }^{26}$ we included only RT-PCR SARS$\mathrm{CoV}-2$-positive patients and coded neurologic disorders based on accepted diagnostic criteria. This is important because inclusion of patients with nonspecific symptoms, unsubstantiated diagnoses, or unverified SARS-CoV-2 infection may lead to inaccurate estimations of prevalence rates. Furthermore, nonspecific symptoms often do not confer the same prognostic implications as specific neurologic diagnoses. Smaller retrospective studies that excluded patients with nonspecific symptoms found much lower neurologic disorder prevalence rates $\left(3.5 \%\right.$ in one study $\left.{ }^{4}\right)$ compared to studies with more liberal inclusion criteria (57\%-84\% in studies ${ }^{1,3}$ that included agitation and fever as possible neurologic disorders). The aforementioned

Table 2 CSF Findings Among Patients With Coronavirus Disease 2019 (COVID-19) With Neurologic Disorders $^{a}(n=26)$

\begin{tabular}{|c|c|}
\hline CSF variable & CSF values \\
\hline WBC count $/ \mathrm{mm}^{3}$ & $2(1-4)$ \\
\hline RBC count & $37(3-656)$ \\
\hline Glucose & $73(59-92)$ \\
\hline Protein & $61(42-106)$ \\
\hline Abnormal WBC count ${ }^{b}$ & $5 / 26(19)$ \\
\hline Abnormal glucose & 0 \\
\hline Abnormal proteinc & $20 / 26(77)$ \\
\hline SARS-CoV-2 CSF PCR negative & $18 / 18(100)$ \\
\hline \multicolumn{2}{|c|}{$\begin{array}{l}\text { Abbreviations: RBC = red blood cells; SARS-CoV- } 2=\text { severe acute respiratory } \\
\text { syndrome coronavirus } 2 \text {; WBC = white blood cells. } \\
\text { Normal laboratory reference range for CSF: WBC }<5 / \mathrm{mm}^{3} \text {; glucose } 40-70 \\
\text { mg/dL or } \geq 2 / 3 \text { of plasma glucose; protein } 15-40 \mathrm{mg} / \mathrm{dL} \text {. Values are median } \\
\text { (interquartile range) or n/total } \mathrm{n}(\%) \text {. } \\
\text { a The CSF studies were normal among all } 4 \text { patients who had CSF collected } \\
\text { but no new neurologic disorder. } \\
\text { b One patient with pleocytosis had a brain mass since September } 2019 \text {, prior } \\
\text { to COVID-19 diagnosis; } 1 \text { patient had pleocytosis that was not present after } \\
\text { correcting for RBCs; } 2 \text { patients with intracerebral and intraventricular } \\
\text { hemorrhage had pleocytosis referable to the hemorrhage; and } 1 \text { patient } \\
\text { had pleocytosis in the context of herpes encephalitis that predated his } \\
\text { COVID-19 symptom onset by } 4 \text { weeks. Repeat CSF studies during his COVID- } \\
19 \text { admission showed improving pleocytosis. } \\
\text { 'CSF protein was elevated in } 3 \text { patients with Guillain-Barré syndrome and } 17 \\
\text { patients with traumatic lumbar punctures with elevated RBC. }\end{array}$} \\
\hline
\end{tabular}

retrospective studies all depended on EMR coding for data extraction and are thus limited by the quality and extent of available documentation. There was limited reporting on imaging studies performed in these retrospective studies, which may indicate an underestimation of neurologic disease or a degree of diagnostic uncertainty. Despite logistical difficulties obtaining neuroimaging in patients with COVID-19 (many of whom were critically ill, intubated, hypoxic, and on multiple vasopressors), $84 \%$ of patients with neurologic disorders in our cohort had head CT imaging and $15 \%$ had brain MRI. As with other centers that faced a surge of patients with COVID-19, workforce strains and contagion containment may have contributed to delays in neurologic diagnoses.

Overall, toxic/metabolic encephalopathy, seizure, and hypoxic/ischemic brain injury were particularly common in our cohort. These complications are also common among critically ill patients, especially those with acute respiratory distress syndrome, sepsis, ${ }^{27}$ hypoxia, acute renal failure, and hypotension, which were prevalent complications among patients with severe COVID-19. Indeed, seizure, hypoxic/ ischemic brain injury, myopathy, neuropathy, and stroke constituted a higher proportion of neurologic complications diagnosed postadmission compared to preadmission (or concurrent with admission). Many of the cases of neuropathy and myopathy in this cohort were attributed to critical illness. There was also a significant association between severity of illness markers (intubation, SOFA scores, acute renal failure) and the occurrence of neurologic disorders, particularly among those who developed neurologic findings after admission, suggesting that critical illness itself may have contributed to neurologic complications. Notably, toxic/ metabolic encephalopathy manifested more frequently prior to or at the time of admission. This may be an artifact of the fact that we were unable to diagnose encephalopathy in patients in whom sedation may have confounded the neurologic examination.

We did not identify any neurologic cases (meningitis, encephalitis, myelitis, or other) that were conclusively related to direct SARS-CoV-2 invasion of the CNS. Indeed, 18/18 (100\%) CSF samples that were tested were RT-PCRnegative for SARS-CoV-2. We did not have any neuropathologic specimens available in this cohort. Our findings do not eliminate the possibility of direct nervous system invasion of SARS-CoV-2; however, given our large sample size it is likely that such a complication is rare. The possibility of endothelial or microvascular viral invasion ${ }^{28,29}$ has been hypothesized to account for some of the unusual strokes and ICHs reported in the context of SARS-CoV-2 infection, yet this remains speculative without pathologic verification. Autopsy series have reported primarily hypoxic-ischemic neuropathologic changes, without evidence of primary viral CNS invasion among patients who presented with nonspecific symptoms of headache, dysgeusia, and myalgias. ${ }^{30}$ An autopsy report of a patient with baseline confusion related to Parkinson disease 
Table 3 Neurologic Disorders Prior to or at the Time of Admission Compared to Neurologic Disorders After Admission Among Patients With Coronavirus Disease 2019a

\begin{tabular}{|c|c|c|c|}
\hline & $\begin{array}{l}\text { Neurologic disorder preadmit or at time of } \\
\text { admission }(n=419)\end{array}$ & $\begin{array}{l}\text { Neurologic disorder postadmission } \\
(n=180)\end{array}$ & $\begin{array}{l}p \\
\text { Value }\end{array}$ \\
\hline $\begin{array}{l}\text { Days from admission to first neurologic } \\
\text { symptom }\end{array}$ & $-0.8(-3.5$ to -0.5$)$ & $12.3(5.2-21.2)$ & $<0.001$ \\
\hline \multicolumn{4}{|l|}{ Demographics and clinical findings } \\
\hline Age, y & $74(62-83)$ & $64(57-72)$ & $<0.001$ \\
\hline Male sex & $248 / 419(62)$ & $135 / 180(75)$ & 0.002 \\
\hline Race (white vs other) & $268 / 419(64)$ & $109 / 180(61)$ & 0.429 \\
\hline Maximum SOFA score & $3(0-4)$ & $11(4-14)$ & $<0.001$ \\
\hline Invasive mechanical ventilation & $97 / 419(23)$ & 138/180 (77) & $<0.001$ \\
\hline Acute renal failure & $84 / 419(20)$ & $80 / 180(44)$ & $<0.001$ \\
\hline Comfort care status & $72 / 419(17)$ & $39 / 180(22)$ & 0.195 \\
\hline \multicolumn{4}{|l|}{ Neurologic disorder type } \\
\hline Toxic/metabolic encephalopathy ${ }^{a}$ & $240 / 419(57)$ & $71 / 180(40)$ & $<0.001$ \\
\hline Stroke (any type) & $33 / 419(8)$ & $25 / 180(14)$ & 0.023 \\
\hline Ischemic/TIA & $37 / 419(9)$ & $43 / 180(24)$ & $<0.001$ \\
\hline $\mathrm{ICH} / \mathrm{IVH}$ & $3 / 419(1)$ & $17 / 180(10)$ & $<0.001$ \\
\hline $\begin{array}{l}\text { Spontaneous subarachnoid } \\
\text { hemorrhage }\end{array}$ & 0 & $2 / 180(1)$ & 0.031 \\
\hline Seizure (clinical or electrographic) & $38 / 419(9)$ & $29 / 180(16)$ & 0.013 \\
\hline Hypoxic/ischemic brain injury & $29 / 342(9)$ & $35 / 154(23)$ & $<0.001$ \\
\hline Movement disorder & $23 / 419$ (5) & $17 / 180(9)$ & 0.076 \\
\hline Neuropathy & $17 / 419(4)$ & $17 / 180(9)$ & 0.012 \\
\hline Myopathy & $9 / 418(2)$ & $12 / 178(7)$ & 0.013 \\
\hline Guillain-Barré syndrome & $3(100)$ & 0 & 0.255 \\
\hline Encephalitis/meningitis & 0 & 0 & - \\
\hline Myelopathy/myelitis & 0 & 0 & - \\
\hline \multicolumn{4}{|l|}{ Outcomes } \\
\hline Discharged home & $161 / 219(38)$ & $40 / 180(22)$ & 0.001 \\
\hline Died in hospital & $134 / 419(32)$ & $72 / 180(40)$ & 0.058 \\
\hline
\end{tabular}

Abbreviations: ICH = intracerebral hemorrhage; IVH = intraventricular hemorrhage; SOFA = Sequential Organ Failure Assessment.

Values are median (interquartile range) or $n /$ total $n(\%)$.

${ }^{a}$ Timing of neurologic disorders missing in 7 patients.

described the presence of virus in neural and capillary endothelium in the frontal lobe, ${ }^{31}$ but immunohistochemistry studies were not performed and rough endoplasmic reticulum may be mistaken for virions in the absence of immunohistochemical or electron microscopy confirmation. Neuropathologic data among patients with specific neurologic events in the context of SARS-CoV-2 infection are lacking. One study of patients with ischemic and hemorrhagic stroke included brain biopsy pathology on 2 patients, but one of these was both SARS-CoV-2 RT-PCR-negative and antibody-negative (and included based on chest CT imaging characteristics alone), while the other was RT-PCR-positive. The authors identified a paucity of endothelial cells in arterioles, venules, and capillaries, but no evidence of inflammation to suggest direct viral involvement or endotheliitis. ${ }^{32}$

Conversely, there are clinical and pathologic data to support the occurrence of postinfectious complications of SARS-CoV- 
Table 4 Demographic, Clinical, and Hospital Outcomes Among Patients With Coronavirus Disease 2019 (COVID-19) With and Without Neurologic Disorders During Hospitalization

\begin{tabular}{|c|c|c|c|}
\hline Characteristics & $\begin{array}{l}\text { COVID-19 positive with neurologic } \\
\text { disorder }(n=606)\end{array}$ & $\begin{array}{l}\text { COVID-19 positive without neurologic } \\
\text { disorder }(n=3,885)\end{array}$ & $\begin{array}{l}p \\
\text { Value }\end{array}$ \\
\hline \multicolumn{4}{|l|}{ Demographics } \\
\hline Age, y & $71(60-80)$ & $63(50-75)$ & $<0.001$ \\
\hline Male sex & $397 / 606(66)$ & $2,210 / 3,885(57)$ & $<0.001$ \\
\hline Body mass index & $27(24-31)$ & $28(25-33)$ & $<0.001$ \\
\hline Race & & & $<0.001$ \\
\hline White & $382 / 606(63)$ & $1734 / 3,885(45)$ & \\
\hline Black & $98 / 606(16)$ & $606 / 3,885(16)$ & \\
\hline Asian & $65 / 606(11)$ & $248 / 3,885(6)$ & \\
\hline Other & $61 / 606(10)$ & $1,297 / 3,885(33)$ & \\
\hline \multicolumn{4}{|l|}{ Past medical history } \\
\hline Hypertension & $287 / 606(47)$ & $1,425 / 3,885(37)$ & $<0.001$ \\
\hline Diabetes & 190/606 (31) & $986 / 3,885(25)$ & 0.002 \\
\hline Hyperlipidemia & 190/606 (31) & $979 / 3,885(25)$ & 0.001 \\
\hline Chronic kidney disease & $97 / 606(16)$ & $400 / 3,885(10)$ & $<0.001$ \\
\hline Obstructive sleep apnea & $29 / 600(5)$ & $156 / 3,863(4)$ & 0.363 \\
\hline Atrial fibrillation & $85 / 600(14)$ & $322 / 3,863(8)$ & $<0.001$ \\
\hline Venous thromboembolism & $58 / 600(10)$ & $217 / 3,863(6)$ & $<0.001$ \\
\hline \multicolumn{4}{|l|}{ Past neurologic history ${ }^{a}$} \\
\hline Ischemic stroke & 116/606 (19) & $275 / 3,885(7)$ & $<0.001$ \\
\hline Seizure/epilepsy & $89 / 606(15)$ & $124 / 3,885(3)$ & $<0.001$ \\
\hline Dementia & $73 / 606(12)$ & $143 / 3,885(4)$ & $<0.001$ \\
\hline Neuropathy & $38 / 606(6)$ & $141 / 3,885(4)$ & 0.002 \\
\hline ICH/IVH & $28 / 606(5)$ & $25 / 3,885(1)$ & $<0.001$ \\
\hline Movement disorder & $20 / 606(3)$ & $59 / 3,885(2)$ & 0.002 \\
\hline Traumatic brain injury & $15 / 606(3)$ & $36 / 3,885(1)$ & 0.003 \\
\hline $\begin{array}{l}\text { Multiple sclerosis/demyelinating } \\
\text { disease }\end{array}$ & $5 / 606(1)$ & $15 / 3,885(0.4)$ & 0.176 \\
\hline Myasthenia gravis & $1 / 606(0.2)$ & $5 / 3,885(0.1)$ & 0.581 \\
\hline Hydrocephalus & $10 / 606(2)$ & $9 / 3,885(0.2)$ & $<0.001$ \\
\hline Brain tumor & $5 / 606(1)$ & $6 / 3,885(0.2)$ & 0.010 \\
\hline \multicolumn{4}{|l|}{ Clinical findings } \\
\hline ICU vs non-ICU unit & $242 / 600(40)$ & $737 / 3,852$ (19) & $<0.001$ \\
\hline Maximum SOFA score & $4(3-9)$ & $3(0-4)$ & $<0.001$ \\
\hline \multicolumn{4}{|l|}{ Medications } \\
\hline Corticosteroids & $146(24)$ & $697(18)$ & $<0.001$ \\
\hline Hydroxychloroquine & $445 / 606(73)$ & $2,570 / 3,885(66)$ & $<0.001$ \\
\hline Azithromycin & $380 / 606(63)$ & $2,295 / 3,885(59)$ & 0.090 \\
\hline
\end{tabular}


Table 4 Demographic, Clinical, and Hospital Outcomes Among Patients With Coronavirus Disease 2019 (COVID-19) With and Without Neurologic Disorders During Hospitalization (continued)

\begin{tabular}{|c|c|c|c|}
\hline Characteristics & $\begin{array}{l}\text { CoviD-19 positive with neurologic } \\
\text { disorder }(n=606)\end{array}$ & $\begin{array}{l}\text { COVID-19 positive without neurologic } \\
\text { disorder }(n=3,885)\end{array}$ & $\begin{array}{l}p \\
\text { Value }\end{array}$ \\
\hline Lopinavir/ritonavir & $60 / 606(10)$ & $254 / 3,885(7)$ & 0.003 \\
\hline Zinc & $204 / 606$ (34) & $1,359 / 3,885(35)$ & 0.527 \\
\hline Ascorbic acid (vitamin C) & 160/606 (26) & $918 / 3,885(24)$ & 0.137 \\
\hline Tocilizumab & $81 / 606(13)$ & $458 / 3,885(12)$ & 0.266 \\
\hline Remdesivir & $1 / 606(0.2)$ & $13 / 3,885(0.3)$ & 0.709 \\
\hline $\begin{array}{l}\text { Therapeutic anticoagulation }{ }^{\mathrm{b}} \text { (based } \\
\text { on D-dimer) }\end{array}$ & $176 / 606(29)$ & $678 / 3,885(18)$ & $<0.001$ \\
\hline $\begin{array}{l}\text { Therapeutic anticoagulation }{ }^{\mathrm{b}} \text { (clinical } \\
\text { indication }^{\mathrm{c}} \text { ) }\end{array}$ & $75 / 606(12)$ & $216 / 3,885(6)$ & $<0.001$ \\
\hline Acute renal failure & $167 / 606(28)$ & $479 / 3,885(12)$ & $<0.001$ \\
\hline Invasive mechanical ventilation & $241 / 602(40)$ & $746 / 3,885(19)$ & $<0.001$ \\
\hline Hospital length of stay, d & $9.8(4.9-22.6)$ & $5.9(3.0-10.7)$ & $<0.001$ \\
\hline Ventilator, $d^{d}$ & $11.8(3.7-24.0)$ & $5.0(1.2-12.7)$ & $<0.001$ \\
\hline Comfort care status & $111 / 606(18)$ & $156 / 3,885(4)$ & $<0.001$ \\
\hline \multicolumn{4}{|l|}{ Radiographic and laboratory findings } \\
\hline Head CT & $510 / 606(84)$ & $374 / 3,885(10)$ & $<0.001$ \\
\hline Brain MRI & $89 / 606(15)$ & $38 / 3,885(1)$ & $<0.001$ \\
\hline Lumbar puncture & $26 / 606$ (4) & $4 / 3,885(0.1)$ & $<0.001$ \\
\hline Admission interleukin- $6, \mathrm{pg} / \mathrm{mL}^{\mathrm{e}}$ & $32(14-66)$ & $21(10-52)$ & 0.007 \\
\hline Admission C-reactive protein, $\mathrm{mg} / \mathrm{L}^{\mathrm{f}}$ & $93(35-157)$ & $107(50-170)$ & 0.001 \\
\hline Admission D-dimer, $\mathrm{ng} / \mathrm{mL}^{\mathrm{g}}$ & $532(309-1,112)$ & $425(272-791)$ & $<0.001$ \\
\hline Admission ferritin, $\mathrm{ng} / \mathrm{mL}^{\mathrm{h}}$ & $667(317-1,541)$ & $677(317-1,387)$ & 0.379 \\
\hline \multicolumn{4}{|l|}{ Hospital outcomes } \\
\hline Discharged home & $201 / 596(34)$ & $2,548 / 3,803(67)$ & $<0.001$ \\
\hline Died in-hospital & $211 / 606(35)$ & $751 / 3,885(19)$ & $<0.001$ \\
\hline Other discharge dispositions & $187 / 596(32)$ & $504 / 3,803(13)$ & $<0.001$ \\
\hline Hospitalized & $13 / 596(2)$ & $27 / 3,803(1)$ & $<0.001$ \\
\hline LTACH & $14 / 596(2)$ & $28 / 3,803(1)$ & $<0.001$ \\
\hline Nursing home & $122 / 596(21)$ & $357 / 3,803(9)$ & $<0.001$ \\
\hline Acute inpatient rehabilitation & $32 / 596(5)$ & $89 / 3,803(2)$ & $<0.001$ \\
\hline Subacute rehabilitation & 4/596 (1) & $3 / 3,803(0.1)$ & 0.001 \\
\hline
\end{tabular}

Abbreviations: ICH/IVH = intracerebral hemorrhage or intraventricular hemorrhage; ICU = intensive care unit; LTACH = long-term acute care hospital; SOFA = Sequential Organ Failure Assessment.

Values are median (interquartile range) or $\mathrm{n} /$ total $\mathrm{n}(\%)$

a Patients could have more than 1 past neurologic history diagnosis.

${ }^{b}$ Includes therapeutic dosing of enoxaparin or heparin.

' Indications include atrial fibrillation, venous thromboembolism, or mechanical heart valve.

d Includes only patients who received invasive mechanical ventilation.

e Data available in 161 patients with neurologic disorders and 841 patients without neurologic disorders (normal range $\leq 5 \mathrm{pg} / \mathrm{mL}$ ).

' Data available in 577 patients with neurologic disorders and 3,466 patients without neurologic disorders (normal range 0.0-3.0 mg/L).

${ }^{8}$ Data available in 492 patients with neurologic disorders and 2,993 patients without neurologic disorders (normal range $<230 \mathrm{ng} / \mathrm{mL}$ ).

${ }^{n}$ Data available in 573 patients with neurologic disorders and 3,449 patients without neurologic disorders (normal range 8.0-388.0 ng/mL). 
2. We identified 3 patients with Guillain-Barré syndrome occurring within 2-4 weeks of documented SARS-CoV-2 infection. All 3 patients had RT-PCR SARS-CoV-2-negative CSF, but antibody testing in the CSF was not available. Because a number of other studies have reported SARS-CoV-2 complications including Guillain-Barré syndrome and acute disseminated encephalomyelitis, the possibility of postinfectious or parainfectious COVID-19-related complications seems plausible. ${ }^{5,6,33-36}$ One neuropathology report of a critically ill patient with COVID-19 identified atypical white matter lesions, microscopic infarcts, necrosis, and axonal injury on an autopsy performed weeks after SARS-CoV-2 diagnosis. This case was thought to represent a postinfectious, possibly autoimmune manifestation of COVID-19. ${ }^{37}$

In our cohort, patients with COVID-19 with neurologic disorders had significantly higher risk of in-hospital mortality and lower rates of discharge home compared to patients with COVID-19 without neurologic findings. One strength of our analysis was that we were able to adjust for a variety of other factors including comfort care status, which often confounds mortality analyses. In a separate study, we found that patients with laboratory-confirmed COVID-19 and ischemic stroke have higher mortality rates than contemporary and historical patients with ischemic stroke who did not have COVID-19. ${ }^{25}$ Others have found similar increases in mortality rates among patients with a spectrum of SARS-CoV-2-related neurologic diseases ${ }^{38}$ compared to contemporary COVID-19-negative neurologic patients. We studied neurologic events as a time-dependent variable to avoid the immortal time bias, which can occur when an event is observed more frequently in patients who survive long enough to be diagnosed. This methodology also allowed us to account for the duration of exposure to neurologic injury when predicting the hazard of in-hospital death.

There are limitations to this study that should be mentioned. First, patients with limited neurologic examinations due to sedation or paralysis may have had neurologic disorders that were undetected, leading to underestimations in the prevalence of COVID-19-related neurologic injury. Furthermore, neurology may not have been consulted on patients with mild neurologic symptoms. Logistical difficulties in transporting patients for neuroimaging studies may have also led to underestimations of neurologic disorders. However, the fact that neurologists and neurointensivists in our health system cross covered COVID-19 medicine patients during the time epoch of this study increases the likelihood that neurologic disorders were detected. Second, neurologic disorders may have occurred in patients who did not come to hospital ${ }^{25,39,40}$ due to fear of contracting COVID-19. Third, due to illness severity, many patients may not have been able to provide a detailed history of neurologic symptoms, which could contribute to underestimations of prevalence. Lastly, due to high rates of missing data, we were unable to report rates of Hispanic ethnicity.

Neurologic disorders were detected in $13.5 \%$ of patients with COVID-19 during the study timeframe. Many of these neurologic disorders occur commonly among patients with critical illness. Encephalitis, meningitis, or myelitis referable to SARS-CoV-2 infection did not occur, although postinfectious Guillain-Barré syndrome was identified. Overall, neurologic disorders in the context of SARS-CoV-2 infection confer a higher risk of in-hospital mortality and reduced likelihood of discharge home.

\section{Study Funding}

No targeted funding reported.

\section{Disclosure}

J. Frontera received grant support from NIH/NIA 3P30AG066512-01S1 and NIH/NINDS 3U24NS11384401S1 for the study of neurologic disorders in COVID-19. S. Sabadia, R. Lalchan, T. Fang, B. Flusty, P. Millar-Vernetti, T. Snyder, S. Berger, D. Yang, A. Granger, N. Morgan, P. Patel, J. Gutman, K. Melmed, S. Agarwal, M. Bokhari, A. Andino, E. Valdes, M. Omari, A. Kvernland, and K. Lillemoe report no disclosures. S. Chou reports University of Pittsburgh CTSI award for study of neurologic manifestations of COVID-19. M. McNett, R. Helbok, S. Mainali, E. Fink, C. Robertson, M. Schober, J. Suarez, W. Ziai, D. Menon, D. Friedman, D. Friedman, M. Holmes, J. Huang, S. Thawani, J. Howard, N. Abou-Fayssal, P. Krieger, A. Lewis, A. Lord, T. Zhou, D.E. Kahn, B. Czeisler, J. Torres, S. Yaghi, K. Ishida, E. Scher, A. de Havenon, D. Placantonakis, and M. Liu report no disclosures. T. Wisniewski received grant support from NIH/NIA 3P30AG066512-01S1 for the study of COVID-19 effects on the aging. A. Troxel received grant support from NIH/ NINDS 3U24NS11384401S1 for the study of neurologic disorders in COVID-19. L. Balcer received grant support from NIH/NIA 3P30AG066512-01S1 for the study of COVID-19 effects on the aging. S. Galetta-reports no disclosures. Go to Neurology.org/ $\mathrm{N}$ for full disclosures.

\section{Publication History}

Received by Neurology July 14, 2020. Accepted in final form September 14, 2020.

Appendix Authors

\begin{tabular}{lll}
\hline Name & Location & Contribution \\
\hline $\begin{array}{l}\text { Jennifer A. } \\
\text { Frontera, MD }\end{array}$ & $\begin{array}{l}\text { NYU Langone } \\
\text { Hospitals, New } \\
\text { York }\end{array}$ & $\begin{array}{l}\text { Design, data acquisition, data } \\
\text { analysis and interpretation, } \\
\text { drafted and devised manuscript }\end{array}$ \\
\hline $\begin{array}{l}\text { Sakinah } \\
\text { Sabadia, MD }\end{array}$ & $\begin{array}{l}\text { NYU Langone } \\
\text { Hospitals, New } \\
\text { York }\end{array}$ & $\begin{array}{l}\text { Design, data acquisition, revised } \\
\text { the manuscript for intellectual } \\
\text { content }\end{array}$ \\
$\begin{array}{l}\text { Rebecca } \\
\text { Lalchan, DO }\end{array}$ & $\begin{array}{l}\text { NYU Langone } \\
\text { Yospitals, New }\end{array}$ & $\begin{array}{l}\text { Data acquisition, revised the } \\
\text { manuscript for intellectual } \\
\text { content }\end{array}$ \\
\hline $\begin{array}{l}\text { Taolin Fang, } \\
\text { MD }\end{array}$ & $\begin{array}{l}\text { NYU Langone } \\
\text { Hospitals, New }\end{array}$ & $\begin{array}{l}\text { Data acquisition, revised the } \\
\text { manuscript for intellectual } \\
\text { content }\end{array}$ \\
\hline $\begin{array}{l}\text { Bork } \\
\text { Do }\end{array}$ & $\begin{array}{l}\text { NYU Langone } \\
\text { Hospitals, New }\end{array}$ & $\begin{array}{l}\text { Data acquisition, revised the } \\
\text { manuscript for intellectual } \\
\text { content }\end{array}$ \\
\hline
\end{tabular}


Appendix (continued)

\begin{tabular}{|c|c|c|}
\hline Name & Location & Contribution \\
\hline $\begin{array}{l}\text { Patricio Millar- } \\
\text { Vernetti, MD }\end{array}$ & $\begin{array}{l}\text { NYU Langone } \\
\text { Hospitals, New } \\
\text { York }\end{array}$ & $\begin{array}{l}\text { Data acquisition, revised the } \\
\text { manuscript for intellectual } \\
\text { content }\end{array}$ \\
\hline $\begin{array}{l}\text { Thomas } \\
\text { Snyder, MD }\end{array}$ & $\begin{array}{l}\text { NYU Langone } \\
\text { Hospitals, New } \\
\text { York }\end{array}$ & $\begin{array}{l}\text { Data acquisition, revised the } \\
\text { manuscript for intellectual } \\
\text { content }\end{array}$ \\
\hline $\begin{array}{l}\text { Stephen } \\
\text { Berger, MD }\end{array}$ & $\begin{array}{l}\text { NYU Langone } \\
\text { Hospitals, New } \\
\text { York }\end{array}$ & $\begin{array}{l}\text { Data acquisition, revised the } \\
\text { manuscript for intellectual } \\
\text { content }\end{array}$ \\
\hline $\begin{array}{l}\text { Dixon Yang, } \\
\text { MD }\end{array}$ & $\begin{array}{l}\text { NYU Langone } \\
\text { Hospitals, New } \\
\text { York }\end{array}$ & $\begin{array}{l}\text { Data acquisition, revised the } \\
\text { manuscript for intellectual } \\
\text { content }\end{array}$ \\
\hline $\begin{array}{l}\text { Andre Granger, } \\
\text { MD }\end{array}$ & $\begin{array}{l}\text { NYU Langone } \\
\text { Hospitals, New } \\
\text { York }\end{array}$ & $\begin{array}{l}\text { Data acquisition, revised the } \\
\text { manuscript for intellectual } \\
\text { content }\end{array}$ \\
\hline $\begin{array}{l}\text { Nicole Morgan, } \\
\text { MD }\end{array}$ & $\begin{array}{l}\text { NYU Langone } \\
\text { Hospitals, New } \\
\text { York }\end{array}$ & $\begin{array}{l}\text { Data acquisition, revised the } \\
\text { manuscript for intellectual } \\
\text { content }\end{array}$ \\
\hline $\begin{array}{l}\text { Palak Patel, } \\
\text { MD }\end{array}$ & $\begin{array}{l}\text { NYU Langone } \\
\text { Hospitals, New } \\
\text { York }\end{array}$ & $\begin{array}{l}\text { Data acquisition, revised the } \\
\text { manuscript for intellectual } \\
\text { content }\end{array}$ \\
\hline $\begin{array}{l}\text { Josef Gutman, } \\
\text { MD }\end{array}$ & $\begin{array}{l}\text { NYU Langone } \\
\text { Hospitals, New } \\
\text { York }\end{array}$ & $\begin{array}{l}\text { Data acquisition, revised the } \\
\text { manuscript for intellectual } \\
\text { content }\end{array}$ \\
\hline $\begin{array}{l}\text { Kara Melmed, } \\
\text { MD }\end{array}$ & $\begin{array}{l}\text { NYU Langone } \\
\text { Hospitals, New } \\
\text { York }\end{array}$ & $\begin{array}{l}\text { Data acquisition, revised the } \\
\text { manuscript for intellectual } \\
\text { content }\end{array}$ \\
\hline $\begin{array}{l}\text { Shashank } \\
\text { Agarwal, MD }\end{array}$ & $\begin{array}{l}\text { NYU Langone } \\
\text { Hospitals, New } \\
\text { York }\end{array}$ & $\begin{array}{l}\text { Data acquisition, revised the } \\
\text { manuscript for intellectual } \\
\text { content }\end{array}$ \\
\hline $\begin{array}{l}\text { Matthew } \\
\text { Bokhari, MD }\end{array}$ & $\begin{array}{l}\text { NYU Langone } \\
\text { Hospitals, New } \\
\text { York }\end{array}$ & $\begin{array}{l}\text { Data acquisition, revised the } \\
\text { manuscript for intellectual } \\
\text { content }\end{array}$ \\
\hline $\begin{array}{l}\text { Andres Andino, } \\
\text { MD }\end{array}$ & $\begin{array}{l}\text { NYU Langone } \\
\text { Hospitals, New } \\
\text { York }\end{array}$ & $\begin{array}{l}\text { Data acquisition, revised the } \\
\text { manuscript for intellectual } \\
\text { content }\end{array}$ \\
\hline $\begin{array}{l}\text { Eduard Valdes, } \\
\text { MD }\end{array}$ & $\begin{array}{l}\text { NYU Langone } \\
\text { Hospitals, New } \\
\text { York }\end{array}$ & $\begin{array}{l}\text { Data acquisition, revised the } \\
\text { manuscript for intellectual } \\
\text { content }\end{array}$ \\
\hline $\begin{array}{l}\text { Mirza Omari, } \\
\text { MD }\end{array}$ & $\begin{array}{l}\text { NYU Langone } \\
\text { Hospitals, New } \\
\text { York }\end{array}$ & $\begin{array}{l}\text { Data acquisition, revised the } \\
\text { manuscript for intellectual } \\
\text { content }\end{array}$ \\
\hline $\begin{array}{l}\text { Alexandra } \\
\text { Kvernland, MD }\end{array}$ & $\begin{array}{l}\text { NYU Langone } \\
\text { Hospitals, New } \\
\text { York }\end{array}$ & $\begin{array}{l}\text { Data acquisition, revised the } \\
\text { manuscript for intellectual } \\
\text { content }\end{array}$ \\
\hline $\begin{array}{l}\text { Kaitlyn } \\
\text { Lillemoe, mD }\end{array}$ & $\begin{array}{l}\text { NYU Langone } \\
\text { Hospitals, New } \\
\text { York }\end{array}$ & $\begin{array}{l}\text { Data acquisition, revised the } \\
\text { manuscript for intellectual } \\
\text { content }\end{array}$ \\
\hline $\begin{array}{l}\text { Sherry H.-Y. } \\
\text { Chou, MD, MSc }\end{array}$ & $\begin{array}{l}\text { UPMC, } \\
\text { Pittsburgh, PA }\end{array}$ & $\begin{array}{l}\text { Design, data interpretation, } \\
\text { revised the manuscript for } \\
\text { intellectual content }\end{array}$ \\
\hline $\begin{array}{l}\text { Molly McNett, } \\
\text { RN, PhD }\end{array}$ & $\begin{array}{l}\text { Ohio State } \\
\text { University, } \\
\text { Columbus }\end{array}$ & $\begin{array}{l}\text { Design, data interpretation, } \\
\text { revised the manuscript for } \\
\text { intellectual content }\end{array}$ \\
\hline $\begin{array}{l}\text { Raimund } \\
\text { Helbok, MD, } \\
\text { PhD }\end{array}$ & $\begin{array}{l}\text { Medical } \\
\text { University of } \\
\text { Innsbruck, } \\
\text { Austria }\end{array}$ & $\begin{array}{l}\text { Design, data interpretation, } \\
\text { revised the manuscript for } \\
\text { intellectual content }\end{array}$ \\
\hline
\end{tabular}

Appendix (continued)

\begin{tabular}{|c|c|c|}
\hline Name & Location & Contribution \\
\hline $\begin{array}{l}\text { Shraddha } \\
\text { Mainali, MD }\end{array}$ & $\begin{array}{l}\text { Ohio State } \\
\text { University, } \\
\text { Columbus }\end{array}$ & $\begin{array}{l}\text { Design, data interpretation, } \\
\text { revised the manuscript for } \\
\text { intellectual content }\end{array}$ \\
\hline $\begin{array}{l}\text { Ericka L. Fink, } \\
\text { MD }\end{array}$ & $\begin{array}{l}\text { UPMC, } \\
\text { Pittsburgh, PA }\end{array}$ & $\begin{array}{l}\text { Design, data interpretation, } \\
\text { revised the manuscript for } \\
\text { intellectual content }\end{array}$ \\
\hline $\begin{array}{l}\text { Courtney } \\
\text { Robertson, MD }\end{array}$ & $\begin{array}{l}\text { Johns Hopkins } \\
\text { University, } \\
\text { Baltimore, MD }\end{array}$ & $\begin{array}{l}\text { Design, data interpretation, } \\
\text { revised the manuscript for } \\
\text { intellectual content }\end{array}$ \\
\hline $\begin{array}{l}\text { Michelle } \\
\text { Schober, MD }\end{array}$ & $\begin{array}{l}\text { University of } \\
\text { Utah, Salt Lake } \\
\text { City }\end{array}$ & $\begin{array}{l}\text { Design, data interpretation, } \\
\text { revised the manuscript for } \\
\text { intellectual content }\end{array}$ \\
\hline $\begin{array}{l}\text { Jose I. Suarez, } \\
\text { MD }\end{array}$ & $\begin{array}{l}\text { Johns Hopkins } \\
\text { University, } \\
\text { Baltimore, MD }\end{array}$ & $\begin{array}{l}\text { Data interpretation, revised the } \\
\text { manuscript for intellectual } \\
\text { content }\end{array}$ \\
\hline Wendy Ziai, MD & $\begin{array}{l}\text { Johns Hopkins } \\
\text { University, } \\
\text { Baltimore, MD }\end{array}$ & $\begin{array}{l}\text { Data interpretation, revised the } \\
\text { manuscript for intellectual } \\
\text { content }\end{array}$ \\
\hline $\begin{array}{l}\text { David Menon, } \\
\text { mD, PhD }\end{array}$ & $\begin{array}{l}\text { Cambridge } \\
\text { University, UK }\end{array}$ & $\begin{array}{l}\text { Data interpretation, revised the } \\
\text { manuscript for intellectual } \\
\text { content }\end{array}$ \\
\hline $\begin{array}{l}\text { Daniel } \\
\text { Friedman, MD }\end{array}$ & $\begin{array}{l}\text { NYU Langone } \\
\text { Hospitals, New } \\
\text { York }\end{array}$ & $\begin{array}{l}\text { Data acquisition and interpretation, } \\
\text { revised the manuscript for } \\
\text { intellectual content }\end{array}$ \\
\hline $\begin{array}{l}\text { David } \\
\text { Friedman, MD }\end{array}$ & $\begin{array}{l}\text { NYU Langone } \\
\text { Hospitals, New } \\
\text { York }\end{array}$ & $\begin{array}{l}\text { Data acquisition, revised the } \\
\text { manuscript for intellectual } \\
\text { content }\end{array}$ \\
\hline $\begin{array}{l}\text { Manisha } \\
\text { Holmes, MD }\end{array}$ & $\begin{array}{l}\text { NYU Langone } \\
\text { Hospitals, New } \\
\text { York }\end{array}$ & $\begin{array}{l}\text { Data acquisition and } \\
\text { interpretation, revised the } \\
\text { manuscript for intellectual } \\
\text { content }\end{array}$ \\
\hline $\begin{array}{l}\text { Joshua Huang, } \\
\text { MSc }\end{array}$ & $\begin{array}{l}\text { NYU Langone } \\
\text { Hospitals, New } \\
\text { York }\end{array}$ & $\begin{array}{l}\text { Data acquisition, revised the } \\
\text { manuscript for intellectual } \\
\text { content }\end{array}$ \\
\hline $\begin{array}{l}\text { Sujata } \\
\text { Thawani, MD }\end{array}$ & $\begin{array}{l}\text { NYU Langone } \\
\text { Hospitals, New } \\
\text { York }\end{array}$ & $\begin{array}{l}\text { Data acquisition, revised the } \\
\text { manuscript for intellectual } \\
\text { content }\end{array}$ \\
\hline $\begin{array}{l}\text { Jonathan } \\
\text { Howard, MD }\end{array}$ & $\begin{array}{l}\text { NYU Langone } \\
\text { Hospitals, New } \\
\text { York }\end{array}$ & $\begin{array}{l}\text { Data acquisition, revised the } \\
\text { manuscript for intellectual } \\
\text { content }\end{array}$ \\
\hline $\begin{array}{l}\text { Nada Abou- } \\
\text { Fayssal, MD }\end{array}$ & $\begin{array}{l}\text { NYU Langone } \\
\text { Hospitals, New } \\
\text { York }\end{array}$ & $\begin{array}{l}\text { Data acquisition, revised the } \\
\text { manuscript for intellectual } \\
\text { content }\end{array}$ \\
\hline $\begin{array}{l}\text { Penina Krieger, } \\
\text { MPhil }\end{array}$ & $\begin{array}{l}\text { NYU Langone } \\
\text { Hospitals, New } \\
\text { York }\end{array}$ & $\begin{array}{l}\text { Data acquisition, revised the } \\
\text { manuscript for intellectual } \\
\text { content }\end{array}$ \\
\hline $\begin{array}{l}\text { Ariane Lewis, } \\
\text { MD }\end{array}$ & $\begin{array}{l}\text { NYU Langone } \\
\text { Hospitals, New } \\
\text { York }\end{array}$ & $\begin{array}{l}\text { Data interpretation, revised the } \\
\text { manuscript for intellectual } \\
\text { content }\end{array}$ \\
\hline $\begin{array}{l}\text { Aaron S. Lord, } \\
\text { MD }\end{array}$ & $\begin{array}{l}\text { NYU Langone } \\
\text { Hospitals, New } \\
\text { York }\end{array}$ & $\begin{array}{l}\text { Data interpretation, revised the } \\
\text { manuscript for intellectual } \\
\text { content }\end{array}$ \\
\hline Ting Zhou, MD & $\begin{array}{l}\text { NYU Langone } \\
\text { Hospitals, New } \\
\text { York }\end{array}$ & $\begin{array}{l}\text { Data interpretation, revised the } \\
\text { manuscript for intellectual } \\
\text { content }\end{array}$ \\
\hline $\begin{array}{l}\text { D. Ethan Kahn, } \\
\text { DO }\end{array}$ & $\begin{array}{l}\text { NYU Langone } \\
\text { Hospitals, New } \\
\text { York }\end{array}$ & $\begin{array}{l}\text { Data interpretation, revised the } \\
\text { manuscript for intellectual } \\
\text { content }\end{array}$ \\
\hline
\end{tabular}

Continued 
Appendix (continued)

\begin{tabular}{|c|c|c|}
\hline Name & Location & Contribution \\
\hline $\begin{array}{l}\text { Barry M. } \\
\text { Czeisler, MD }\end{array}$ & $\begin{array}{l}\text { NYU Langone } \\
\text { Hospitals, New } \\
\text { York }\end{array}$ & $\begin{array}{l}\text { Data interpretation, revised the } \\
\text { manuscript for intellectual } \\
\text { content }\end{array}$ \\
\hline Jose Torres, MD & $\begin{array}{l}\text { NYU Langone } \\
\text { Hospitals, New } \\
\text { York }\end{array}$ & $\begin{array}{l}\text { Data interpretation, revised the } \\
\text { manuscript for intellectual } \\
\text { content }\end{array}$ \\
\hline $\begin{array}{l}\text { Shadi Yaghi, } \\
\text { MD }\end{array}$ & $\begin{array}{l}\text { NYU Langone } \\
\text { Hospitals, New } \\
\text { York }\end{array}$ & $\begin{array}{l}\text { Data interpretation, revised the } \\
\text { manuscript for intellectual } \\
\text { content }\end{array}$ \\
\hline $\begin{array}{l}\text { Koto Ishida, } \\
\text { MD }\end{array}$ & $\begin{array}{l}\text { NYU Langone } \\
\text { Hospitals, New } \\
\text { York }\end{array}$ & $\begin{array}{l}\text { Data interpretation, revised the } \\
\text { manuscript for intellectual } \\
\text { content }\end{array}$ \\
\hline $\begin{array}{l}\text { Erica Scher, RN, } \\
\text { MPH }\end{array}$ & $\begin{array}{l}\text { NYU Langone } \\
\text { Hospitals, New } \\
\text { York }\end{array}$ & $\begin{array}{l}\text { Data interpretation, revised the } \\
\text { manuscript for intellectual } \\
\text { content }\end{array}$ \\
\hline $\begin{array}{l}\text { Adam de } \\
\text { Havenon, MD }\end{array}$ & $\begin{array}{l}\text { University of } \\
\text { Utah, Salt Lake } \\
\text { City }\end{array}$ & $\begin{array}{l}\text { Data interpretation, revised the } \\
\text { manuscript for intellectual } \\
\text { content }\end{array}$ \\
\hline $\begin{array}{l}\text { Dimitris } \\
\text { Placantonakis, } \\
\text { MD, PhD }\end{array}$ & $\begin{array}{l}\text { NYU Langone } \\
\text { Hospitals, New } \\
\text { York }\end{array}$ & $\begin{array}{l}\text { Data interpretation, revised the } \\
\text { manuscript for intellectual } \\
\text { content }\end{array}$ \\
\hline $\begin{array}{l}\text { Mengling Liu, } \\
\text { PhD }\end{array}$ & $\begin{array}{l}\text { NYU Langone } \\
\text { Hospitals, New } \\
\text { York }\end{array}$ & $\begin{array}{l}\text { Data analysis, revised the } \\
\text { manuscript for intellectual } \\
\text { content }\end{array}$ \\
\hline $\begin{array}{l}\text { Thomas } \\
\text { Wisniewski, } \\
\text { MD }\end{array}$ & $\begin{array}{l}\text { NYU Langone } \\
\text { Hospitals, New } \\
\text { York }\end{array}$ & $\begin{array}{l}\text { Data interpretation, revised the } \\
\text { manuscript for intellectual } \\
\text { content }\end{array}$ \\
\hline $\begin{array}{l}\text { Andrea B. } \\
\text { Troxel, ScD }\end{array}$ & $\begin{array}{l}\text { NYU Langone } \\
\text { Hospitals, New } \\
\text { York }\end{array}$ & $\begin{array}{l}\text { Data analysis, revised the } \\
\text { manuscript for intellectual } \\
\text { content }\end{array}$ \\
\hline $\begin{array}{l}\text { Laura Balcer, } \\
\text { MD, MSCE }\end{array}$ & $\begin{array}{l}\text { NYU Langone } \\
\text { Hospitals, New } \\
\text { York }\end{array}$ & $\begin{array}{l}\text { Data interpretation, revised the } \\
\text { manuscript for intellectual } \\
\text { content }\end{array}$ \\
\hline $\begin{array}{l}\text { Steven Galetta, } \\
\text { MD }\end{array}$ & $\begin{array}{l}\text { NYU Langone } \\
\text { Hospitals, New } \\
\text { York }\end{array}$ & $\begin{array}{l}\text { Data interpretation, revised the } \\
\text { manuscript for intellectual } \\
\text { content }\end{array}$ \\
\hline
\end{tabular}

\section{References}

1. Helms J, Kremer S, Merdji H, et al. Neurologic features in severe SARS-CoV-2 infection. N Engl J Med 2020;382:2268-2270.

2. Mao L, Jin H, Wang M, et al. Neurologic manifestations of hospitalized patients with coronavirus disease 2019 in Wuhan, China. JAMA Neurol 2020;77:683-690.

3. Romero-Sanchez CM, Diaz-Maroto I, Fernandez-Diaz E, et al. Neurologic manifestations in hospitalized patients with COVID-19: the ALBACOVID registry. Neurology 2020;95:e1060-e1070.

4. Xiong W, Mu J, Guo J, et al. New onset neurologic events in people with COVID-19 infection in three regions in China. Neurology 2020;95:e1479-e1487.

5. Ellul MA, Benjamin L, Singh B, et al. Neurological associations of COVID-19. Lancet Neurol 2020;19:767-783.

6. Poyiadji N, Shahin G, Noujaim D, Stone M, Patel S, Griffith B. COVID-19-associated acute hemorrhagic necrotizing encephalopathy: CT and MRI features. Radiology 2020:296:E119-E120.

7. Frontera J, Mainali S, Fink EL, et al. Global consortium study of neurological dysfunction in COVID-19 (GCS-NeuroCOVID): study design and rationale. Neurocrit Care 2020;33:25-34.

8. Agarwal S, Sabadia S, Abou-Fayssal N, Kurzweil A, Balcer LJ, Galetta SL. Training in neurology: flexibility and adaptability of a neurology training program at the epicenter of COVID-19. Neurology 2020;94:e2608-e2614.

9. Agarwal S, Scher E, Rossan-Raghunath N, et al. Acute stroke care in a New York City comprehensive stroke center during the COVID-19 pandemic. J Stroke Cerebrovasc Dis 2020;29:105068.

10. Sacco RL, Kasner SE, Broderick JP, et al. An updated definition of stroke for the 21st century: a statement for healthcare professionals from the American Heart Association/American Stroke Association. Stroke 2013;44:2064-2089.
11. Fokke C, van den Berg B, Drenthen J, Walgaard C, van Doorn PA, Jacobs BC. Diagnosis of Guillain-Barre syndrome and validation of Brighton criteria. Brain 2014; 137:33-43.

12. Kalita J, Misra UK, Das M. Neurophysiological criteria in the diagnosis of different clinical types of Guillain-Barre syndrome. J Neurol Neurosurg Psychiatry 2008;79: 289-293.

13. Sejvar JJ, Kohl KS, Gidudu J, et al. Guillain-Barré syndrome and Fisher syndrome: case definitions and guidelines for collection, analysis, and presentation of immunization safety data. Vaccine 20129:599-612.

14. Tunkel AR, Glaser CA, Bloch KC, et al. The management of encephalitis: clinical practice guidelines by the Infectious Diseases Society of America. Clin Infect Dis 2008;47:303-327.

15. Tunkel AR, Hartman BJ, Kaplan SL, et al. Practice guidelines for the management of bacterial meningitis. Clin Infect Dis 2004;39:1267-1284.

16. Venkatesan A, Tunkel AR, Bloch KC, et al. Case definitions, diagnostic algorithms, and priorities in encephalitis: consensus statement of the international encephalitis consortium. Clin Infect Dis 2013;57:1114-1128.

17. Tunkel AR, Hasbun R, Bhimraj A, et al. 2017 Infectious Diseases Society of America's clinical practice guidelines for healthcare-associated ventriculitis and meningitis. Clin Infect Dis 2017;64:e34-e65.

18. Scott TF, Frohman EM, De Seze J, Gronseth GS, Weinshenker BG Evidence-based guideline: clinical evaluation and treatment of transverse myelitis: report of the Therapeutics and Technology Assessment Subcommittee of the American Academy of Neurology. Neurology 2017;7:2128-2134.

19. Bhimraj A, Morgan RL, Shumaker AH, et al. Infectious Diseases Society of America guidelines on the treatment and management of patients with COVID-19. Clin Infect Dis Epub 2020 Apr 27.

20. Group RC, Horby P, Lim WS, et al. Dexamethasone in hospitalized patients with covid-19: preliminary report. N Engl J Med Epub 2020 Jul 17.

21. Ferreira FL, Bota DP, Bross A, Mélot C, Vincent JL. Serial evaluation of the SOFA score to predict outcome in critically ill patients. JAMA 200286:1754-1758.

22. Vincent JL, Moreno R, Takala J, et al. The SOFA (Sepsis-related Organ Failure Assessment) score to describe organ dysfunction/failure: on behalf of the working group on sepsis-related problems of the European Society of Intensive Care Medicine. Intensive Care Med 1996;22:707-710.

23. Vincent JL, de Mendonca A, Cantraine F, et al. Use of the SOFA score to assess the incidence of organ dysfunction/failure in intensive care units: results of a multicenter, prospective study: working group on sepsis-related problems of the European Society of Intensive Care Medicine. Crit Care Med 1998;26:1793-1800.

24. Valderrama EV, Humbert K, Lord A, Frontera J, Yaghi S. Severe acute respiratory syndrome coronavirus 2 infection and ischemic stroke. Stroke 2020;51: e124-e127.

25. Yaghi S, Ishida K, Torres J, et al. SARS-CoV-2 and stroke in a New York healthcare system. Stroke 2020;51:2002-2011.

26. Paterson RW, Brown RL, Benjamin L, et al. The emerging spectrum of COVID-19 neurology: clinical, radiological and laboratory findings. Brain 2020;143:3104-3120.

27. Oddo M, Carrera E, Claassen J, Mayer SA, Hirsch LJ. Continuous electroencephalography in the medical intensive care unit. Crit Care Med 2009;37:2051-2056.

28. Puelles VG, Lutgehetmann M, Lindenmeyer MT, et al. Multiorgan and renal tropism of SARS-CoV-2. N Engl J Med 2020;383:590-592.

29. Jaunmuktane Z, Mahadeva U, Green A, et al. Microvascular injury and hypoxic damage: emerging neuropathological signatures in COVID-19. Acta Neuropathol 2020;140:397-400.

30. Solomon IH, Normandin E, Bhattacharyya S, et al. Neuropathological features of COVID-19. N Engl J Med 2020;383:989-992.

31. Paniz-Mondolfi A, Bryce C, Grimes Z, et al. Central nervous system involvement by severe acute respiratory syndrome coronavirus-2 (SARS-CoV-2). J Med Virol 2020; 92:699-702.

32. Hernandez-Fernandez F, Valencia HS, Barbella-Aponte RA, et al. Cerebrovascular disease in patients with COVID-19: neuroimaging, histological and clinical description. Brain 2020;143:3089-3103.

33. Camdessanche JP, Morel J, Pozzetto B, Paul S, Tholance Y, Botelho-Nevers E. COVID-19 may induce Guillain-Barré syndrome. Rev Neurol 2020;176:516-518.

34. Zhao H, Shen D, Zhou H, Liu J, Chen S. Guillain-Barre syndrome associated with SARS-CoV-2 infection: causality or coincidence?. Lancet Neurol 2020;19:383-384.

35. Gutierrez-Ortiz C, Mendez A, Rodrigo-Rey S, et al. Miller Fisher syndrome and polyneuritis cranialis in COVID-19. Neurology Epub 2020 Aug 4.

36. Delamarre L, Gollion C, Grouteau G, et al. COVID-19-associated acute necrotising encephalopathy successfully treated with steroids and polyvalent immunoglobulin with unusual IgG targeting the cerebral fibre network. J Neurol Neurosurg Psychiatry Epub 2020 Jul 10.

37. Reichard RR, Kashani KB, Boire NA, Constantopoulos E, Guo Y, Lucchinetti CF. Neuropathology of COVID-19: a spectrum of vascular and acute disseminated en cephalomyelitis (ADEM)-like pathology. Acta Neuropathol 2020;140:1-6.

38. Benussi A, Pilotto A, Premi E, et al. Clinical characteristics and outcomes of inpatients with neurologic disease and COVID-19 in Brescia, Lombardy, Italy. Neurology 2020; 95:e910-e920.

39. Kansagra AP, Goyal MS, Hamilton S, Albers GW. Collateral effect of COVID-19 on stroke evaluation in the United States. N Engl J Med 2020;383:400-401.

40. de Havenon A, Ney J, Callaghan B, et al. A rapid decrease in stroke, acute coronary syndrome, and corresponding interventions at 65 United States hospitals following emergence of COVID-19. medRxiv Epub 2020 May 11. 


\section{Neurology}

\section{A Prospective Study of Neurologic Disorders in Hospitalized Patients With COVID-19 in New York City}

Jennifer A. Frontera, Sakinah Sabadia, Rebecca Lalchan, et al.

Neurology 2021;96; e575-e586 Published Online before print October 5, 2020

DOI 10.1212/WNL.0000000000010979

This information is current as of October 5,2020

\section{Updated Information \& Services}

References

Citations

Subspecialty Collections

Permissions \& Licensing

Reprints including high resolution figures, can be found at: http://n.neurology.org/content/96/4/e575.full

This article cites 33 articles, 6 of which you can access for free at: http://n.neurology.org/content/96/4/e575.full\#ref-list-1

This article has been cited by 6 HighWire-hosted articles: http://n.neurology.org/content/96/4/e575.full\#\#otherarticles

This article, along with others on similar topics, appears in the following collection(s):

\section{Cohort studies}

http://n.neurology.org/cgi/collection/cohort_studies

\section{COVID-19}

http://n.neurology.org/cgi/collection/covid_19

Critical care

http://n.neurology.org/cgi/collection/critical_care

Prevalence studies

http://n.neurology.org/cgi/collection/prevalence_studies

Prognosis

http://n.neurology.org/cgi/collection/prognosis

Information about reproducing this article in parts (figures,tables) or in its entirety can be found online at:

http://www.neurology.org/about/about_the_journal\#permissions

Information about ordering reprints can be found online:

http://n.neurology.org/subscribers/advertise

Neurology ${ }^{\circledR}$ is the official journal of the American Academy of Neurology. Published continuously since 1951, it is now a weekly with 48 issues per year. Copyright (C 2020 American Academy of Neurology. All rights reserved. Print ISSN: 0028-3878. Online ISSN: 1526-632X.

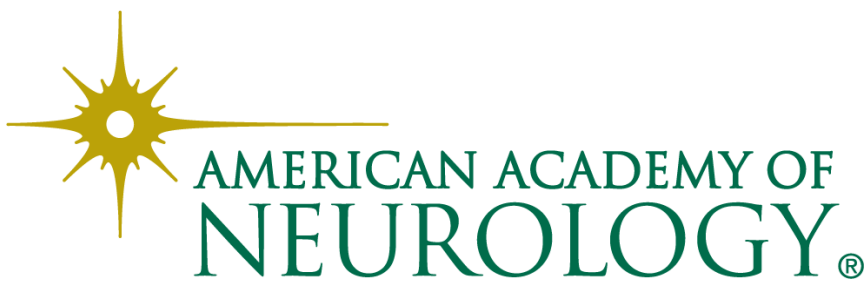

